\title{
Integrated Supply Chain Management and SCOR Model: A Strategic Approach for Small Sized Business
}

\author{
Makkarennu $^{* 1}$, Supratman ${ }^{1}$, Syahidah $^{1}$, Diyah Yumeina $^{2}$, Adelia Caroline $^{1}$ \\ ${ }^{I}$ Faculty of Forestry, Hasanuddin University, Jl. Perintis Kemerdekaan Km. 10 Tamalanrea, \\ Makassar, South Sulawesi, Indonesia \\ ${ }^{I}$ Faculty of Agriculture, Hasanuddin University, Jl. Perintis Kemerdekaan Km. 10 Tamalanrea, Makassar, \\ South Sulawesi, Indonesia Sulawesi, Indonesia
}

\begin{abstract}
This research aims to develop a model of supply chain management and enhance the performance and value of Supply Chain ranging from upstream to downstream with. The location of the research that is in the village of Bonto Sinala sub district of Sinjai Regency, entire stock of Sinjai, South Sulawesi. Method of collecting data through observation, interview and Focus Group Discussion at the community involved in the efforts of Palm sugar, local traders as well as local government. The plan of implementation of the research done at some stage i.e. pre conditions, stage of data collection and data validation stage. Analysis of the data is done through the Implementation through the application of Supply Chain Operations Reference (SCOR) and the Analytical Hierarchy Process. The results showed that the performance of the business performance of Palm sugar is included in the category of average with a total of 46 . The final value of the highest performance shows that are on the process of source and lowest performance on the process of return. This means that the process of hail return requires a priority repair effort on this Palm sugar.
\end{abstract}

Keywords: Palm sugar, superior product, supply chain, SCOR.

\section{INTRODUCTION}

Nowadays, competitiveness is a significant issue in business [1] to overcome market competition. Competition is a factor that affects the business environment in any industry [2]. The concept of competitiveness is a very broad concept, applied both at macro-economic and micro-economic level [3] in comparison with other firms in the industry, national and international level [4]. Understanding the environment in which a company operates, is a vital part of strategic planning [5]. Therefore, measuring competitive capabilities performance seems an adequate way to describe the manufacturing competitiveness of a company [6]. There is high competition between companies in the industry. To achieve a profit, companies increase supply chain efficiency and reduce costs. Therefore, companies must integrate their processes, and compare them with other companies. In this way; they can analyse, improve and benchmark processes, evaluate process analysis and pinpoint the performance measurements. These performance measurements can easily be measured, and evaluated [7].

Currently, supply chain management has become a critical issue for most manufacturing organizations to gain their competitive edge in today's market [8], have a significant role in corporate efficiency [9] and optimization of business activities [10]. Recently, supply chain management has received much attention not only from academics but also from companies. For efficiency, some companies have applied it by integrating all activities starting from the flow of raw materials, the production process until the distribution of products [11]. In addition, Reference [11] shows that supply chain models seem to focus on only one specific aspect of the supply chain: organization strategy, information technology and individual factors. Unlike supply chain management that integrates the entire process flow, the supply chain is only centered on each activity in each process flow. Only those that are efficient will succeed. In consideration of a Supply Chain to be efficient, it is crucial to understand its principal functions as well as the role played by each function in the Supply Chain's overall efficiency.

Unlike supply chain management that integrates the entire process flow, the supply chain is only centered on each activity in each process flow.

Supply Chain Operations Reference (SCOR) model, which is a diagnostic tool for supply chains, can serve as a strategic tool for such environmental performance [12]. It is developed and maintained by the Supply Chain Council (SCC). The model helps companies make real improvements to their supply chain processes to increase 
the effectiveness of supply chain management. SCOR model provides companies with a basic process modelling tool, an extensive benchmark database by defining a set of supply chain metrics [13]. The SCOR model is an integrated approach in supply chain management to measure the performance of organizational standards at each level of the stage into the supply chain framework through a benchmark, gap analysis and best practice approach for sustainable development [14]. The supply chain Council (2012) assert that the SCOR-model has been developed to describe the business activities associated with all phases of satisfying a customer's demand. In applying the model, organizational or company need to make some adjustments to the performance indicators that will be measured at each level of the supply chain process so that the effectiveness of the measurement is achieved.

This study presents an application and integration of SCOR model and AHP to the small sizes enterprises in palm sugar business. In implementing the management of palm sugar business, the problem faced is that the capacity of the community is still weak in the commercialization of palm sugar produced due to the low quality of their products. So far, the palm sugar produced by the Sinjai community has only been marketed in traditional markets due to the low quality of products and the lack of capacity of the community to carry out their marketing strategies and business development. In addition, the supply chain has not yet integrated the palm sugar products from raw materials to product marketing. The development of palm sugar products which are the regional superior products requires the role of relevant stakeholders and the application of technological innovations at each stage of the process.

\section{A. Study Site}

\section{METHODS}

The research location for the development of palm sugar business in Bonto Sinala village, Sinjai Regency, South Sulawesi Province. The basis for choosing this village is because this village is a village that produces palm sugar with a relatively large number of farmers or producers of palm sugar. Each farmer can produce an average of $10 \mathrm{~kg}$ of sugar a day, so that in the production of brown sugar in one village can reach $1000 \mathrm{~kg}$ to $1,500 \mathrm{~kg}$ per day. Palm (Arenga pinnata) products is one of the flagship products in the Regency Sinjai. Arenga pinnata is a plant that grows in the Regency Sinjai with the potential of palm trees in this region approximately of 26.000 trees (209.41 ha). These palm trees are spread in six districts, namely West Sinjai District, Central Sinjai, South Sinjai, Tellulimpoe, Bulupoddo, and Sinjai Borong District. The number of households involved or making the palm sugar business as a livelihood are 693 households.

Data collection activities are carried out through the Participatory Action Research (PAR) approach. The data to be collected in this study consists of primary data and secondary data. Primary data is obtained through field observations and interviews with farmer groups in sample villages, Local traders who are directly involved in marketing selected products and village officials and Focus Group Discussion (FGD). Primary data includes the resources of palm sugar, management of environmental resources, institutions, access to capital, and postharvest processing, technology used in utilizing and cultivating palm sugar products, as well as supply chains and value chains of palm sugar products. Secondary data is data relating to the general state of the research location obtained from literature studies both from the results of related research and other data that are directly and indirectly related to research, including population data and socio-economic conditions and policies related to utilization and business of palm sugar.

Participatory Action Research in this study through several stages, namely the pre-condition stage, the data collection stage and the data validation stage. The pre-condition stage begins with designing a process where the community (palm sugar business group) in the selected village. Next, socialize with the community in accordance with the research objectives to be achieved in this study. This stage is carried out using the FGD technique involving forest farmer groups, community leaders, and village government figures as well as from the local government

The second stage in this research is data collection. This activity begins by identifying and analysing supply chains and value chains starting from upstream, process and downstream. Further data collection is related to products, prices, promotions, distribution channels, participants, processes and the physical environment. The last step in this research is the data validation stage, which is the process of cross checking and verifying the correctness of the data that has been collected in the data collection phase that has been done previously. The data verification phase is carried out by the FGD method, which involves interested parties in the palm sugar business group. 
The development of the supply chain management model is carried out through the application of the Supply Chain Operation Reference (SCOR) which is integrated with the Analytical Hierarchy Process (AHP).

\section{B. Data Collection Technique}

Data collection activities are carried out through the PAR approach. The data to be collected in this study consists of primary data and secondary data. Primary data is obtained through field observations and interviews with farmer groups in sample villages, Local traders who are directly involved in marketing selected products and village officials and Focus Group Discussion. Primary data includes the resources of palm sugar, management of environmental resources, institutions, access to capital, and post-harvest processing, technology used in utilizing and cultivating palm sugar products, as well as supply chains and value chains of palm sugar products. Secondary data is data relating to the general state of the research location obtained from literature studies both from the results of related research and other data that are directly and indirectly related to research, including population data and socio-economic conditions and policies related to utilization and business of palm sugar. PAR in this study through several stages, namely the pre-condition stage, the data collection stage and the data validation stage. The pre-condition stage begins with designing a process where the community (palm sugar business group) in the selected village. Next, socialize with the community in accordance with the research objectives to be achieved in this study. This stage is carried out using the Focus Group Discussion (FGD) technique involving forest farmer groups, community leaders, and village government figures as well as from the local government.

The second stage in this research is data collection. This activity begins by identifying and analysing supply chains and value chains starting from upstream, process and downstream. Further data collection is related to products, prices, promotions, distribution channels, participants, processes and the physical environment.

The last step in this research is the data validation stage, which is the process of cross checking and verifying the correctness of the data that has been collected in the data collection phase that has been done previously. The data verification phase is carried out by the FGD method, which involves interested parties in the palm sugar business group.

\section{Data Analysis}

The development of the supply chain management model is carried out through the application of the Supply Chain Operation Reference (SCOR) which is integrated with the Analytical Hierarchy Process (AHP). SCOR method is used with some adjustments for key performance indicators (KPI) for five process elements are plan, source, make, deliver and return

\section{RESULT}

\section{A. Supply Chain for Palm Sugar}

Increasing competition in the global market, increasingly competitive product innovations and very high customer expectations for a product forces the palm sugar business unit to invest and focus on business development through a business approach that is appropriate or compatible with the environment. Likewise, the business unit of palm sugar that will be developed, the success of its business is very dependent on the supply chain management (SCM) that they manage.

Supply chain and value chain cannot be separated from the concept of SCM. SCM is a series of management activities starting from planning coordination and controlling all business processes and activities in the supply chain to creating the best consumer value at an efficient cost while still meeting all the needs of other stakeholders and the supply chain. Palm sugar is a product that is widely cultivated by people in Sinjai district. Palm sugar in the district of Sinjai is also quite large, according to data from the Department of Food Crops, Culture and Plantation in 2017, the potential of sugar palm in Sinjai Regency is 25,886 trees with an area of 209.41 ha. This potential consists of trees that have not been effective at 19,738 trees and trees that have been productive (tapped) amounting to 6,083 trees. The sugar palm is spread in six sub-districts, namely West Sinjai District, Central Sinjai, South Sinjai, Tellulimpoe, Bulupoddo, and Sinjai Borong District.

Sinjai Borong Subdistrict is a sub-district that has the largest area, namely an area of $70.10 \mathrm{Ha}$. The number of households involved or making the palm sugar business as a livelihood is 693 households. The production of 
palm sugar in the research locations ranges from $1000 \mathrm{~kg}$ to $1500 \mathrm{~kg} / \mathrm{day}$ where in one village there are approximately 10-15 farmer groups consisting of 10-15 people and each farmer is able to produce around $10 \mathrm{~kg}$ per day.

Some of the supply-chain actors in the palm sugar business in Sinjai Regency consist of farmers collecting sap, sap processing, collectors, traders, retailers and consumers. Supply chain and market chain of palm sugar as shown in Fig. 1.

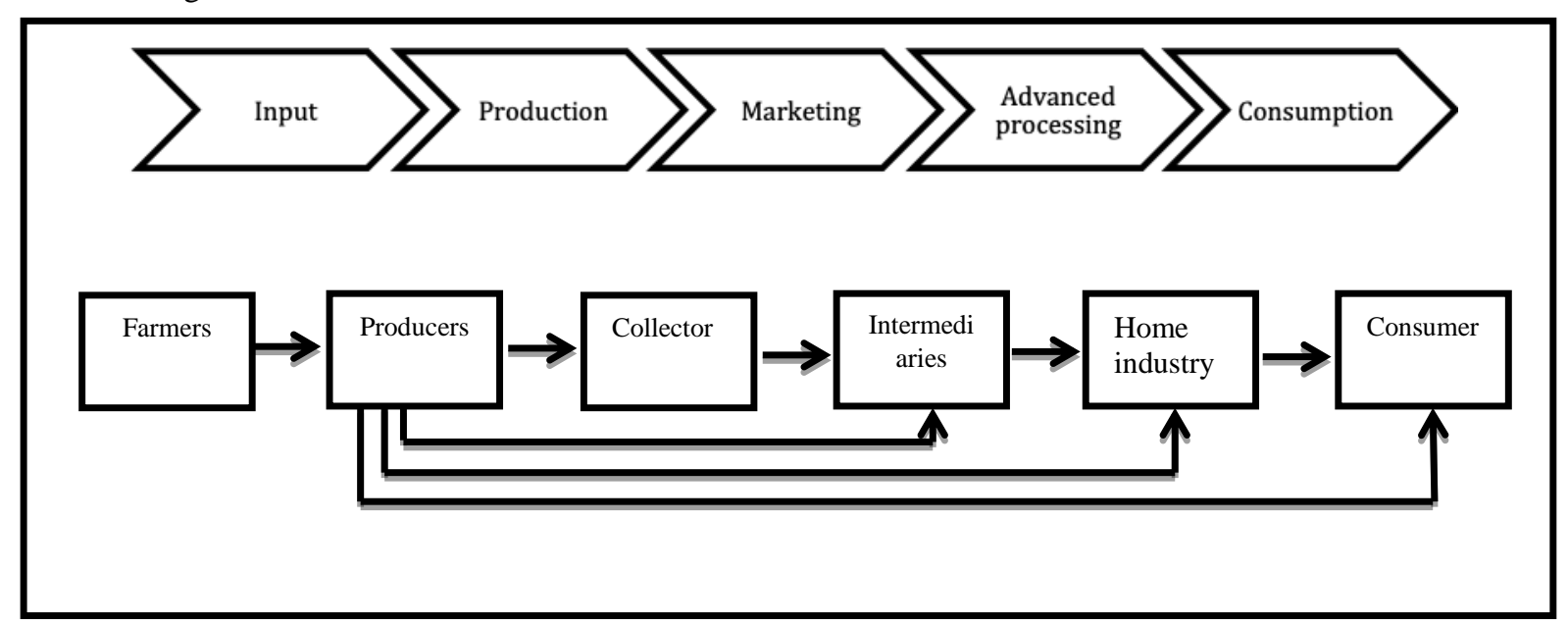

Fig. 1 Supply chain and market chain of palm sugar

Palm sugar farmers who are also mostly palm sugar producers, on average arenga farmers tap palm sugar as much as 2 (two) times, morning and evening. The average number of perpetual leads is 20-30 litters which can be taken in the morning while in the afternoon the average number that can be tapped is 15 litters. The distance between taking nira and palm sugar production house ranges from 50-200 m. Palm sugar producers in Bonto Sinala Village are farmers who produce palm sugar into print sugar and ant sugar. On average, each farmer in the group can produce $10 \mathrm{~kg}$ of print sugar / day with an average selling price of IDR 10,000 (0,67 USD) while the average selling price for ant sugar is IDR 30,000, - IDR 40,000, -. Traders who in this case are collectors and intermediary traders. The relationship between traders and producers is a trusting relationship. Traders usually buy their products after first ordering palm sugar or directly to the sugar palm processor. They collect the products they buy from one farmer to another. Sometimes farmers also sell their products directly to home industries that process palm sugar as a basic ingredient in making traditional cakes.

Main Business Performance Indicators of Palm Sugar

Supply Chain Operation Reference is a reference model of supply chain operations. SCOR is able to map supply chain parts. Basically, SCOR is a process-based model [15]. The application of the SCOR method to the supply chain management provides an overall observation and measurement of the supply chain process. The SCOR model includes three process levels. These three levels indicate that SCOR decomposes the process from the general to the detail. At level 1 the top level (process type) defines the scope for the five core management processes of the SCOR model, namely plan, source, make, deliver and return in the company's supply chain and how their performance is measured. The results of observations and interviews with related parties obtained a total of 27 Key Performance Indicators (KPIs) that represent supply chain conditions. 27 KPIs are then given scores by palm sugar producers.

Priority handling in evaluating the supply chain in the palm sugar business is carried out through the AHP approach on the five scope of the SCOR model's core management process elements, namely plan, source, make, deliver and return in the supply chain sugar palm. Based on the results of validity and reliability tests on 27 questions, 19 validated questions (KPI) were obtained where there were 5 KPIs on element plan, 3 KPI on source elements, 7 KPI on make elements and 2 KPIs on each deliver and return elements.

Priority handling in evaluating the supply chain in the palm sugar business is carried out through the AHP approach on the five scope of the SCOR model's core management process elements, namely plan, source, make, deliver and return in the supply chain sugar palm. Based on the results of validity and reliability tests on 27 
questions, 19 validated questions (KPI) were obtained where there were 5 KPIs on element plan, 3 KPI on source elements, 7 KPI on make elements and 2 KPIs on each deliver and return elements. The performance of the supply chain performance of palm sugar is presented in Fig. 2.

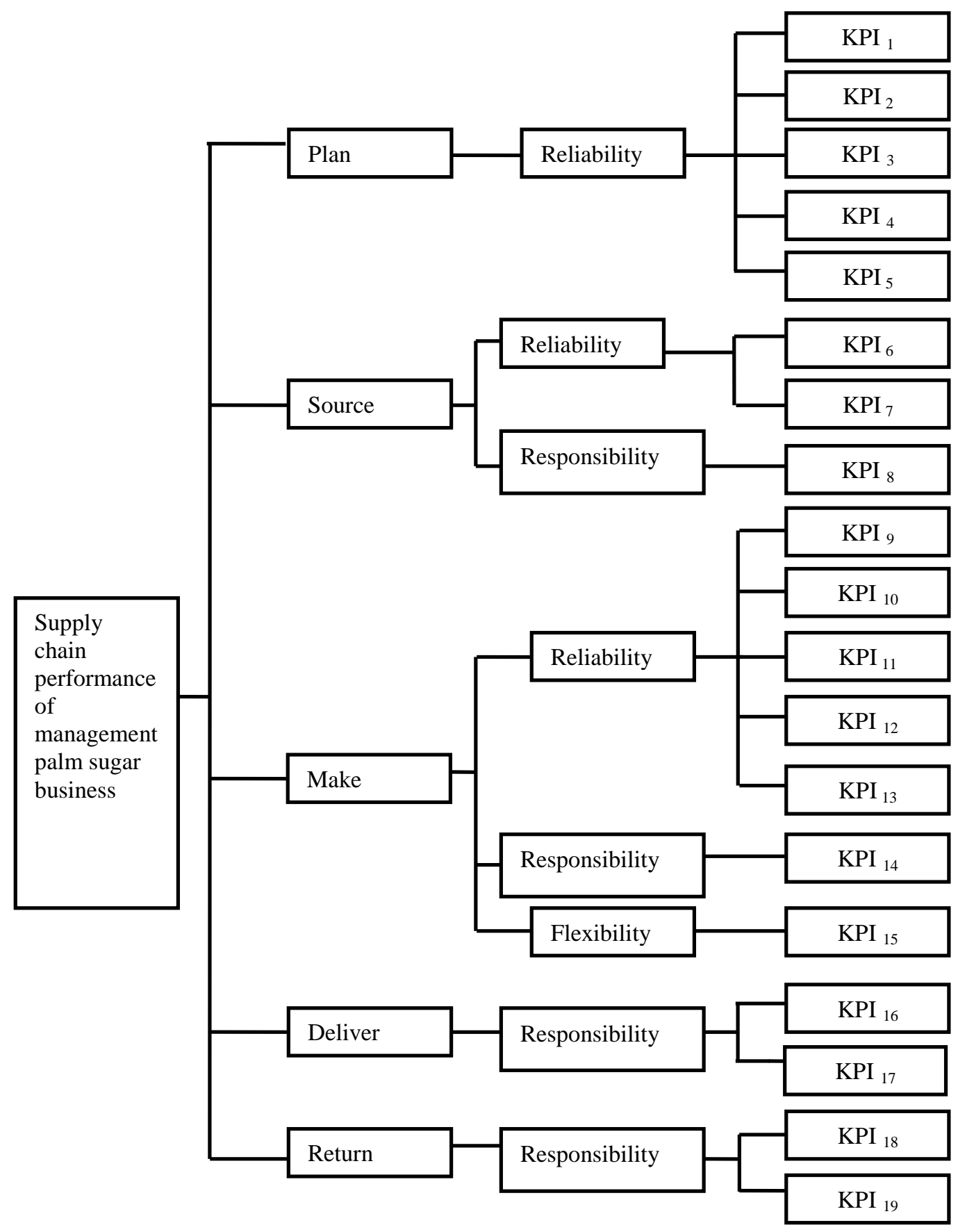

Fig. 2. Performance of supply chain performance of palm sugar

\section{B. Test Validity and Reliability}

Validity test is done by using the SPSS version 16 program which aims to determine the correlation coefficient (rxy) with $\mathrm{r}$ table. The number of samples $(\mathrm{N})$ is 10 respondents or $5 \%$ of the total farmers making brown sugar. If $r$ count is greater than $r$ table then the item is said to be valid otherwise if $r$ count is smaller than 
$\mathrm{r}$ table then the item is said to be invalid. The size of $r$ table is 0.632 . The results of the validity plan test can be seen in Table 1.

Table 1. Validity Test of Plan

\begin{tabular}{|c|c|c|c|c|c|}
\hline No. & Indicators & $\begin{array}{l}\text { KPI } \\
\text { Code }\end{array}$ & $\mathrm{r}_{\mathrm{r} \text { count }}$ & $\begin{array}{c}r_{\text {table }} \\
(d f=n-2, \alpha=5 \%)\end{array}$ & Validity \\
\hline 1 & Predicting accuracy of raw material & KPI 1 & 0,599 & 0.444 & Valid \\
\hline 2 & $\begin{array}{l}\text { The time span required between the order and the time } \\
\text { of arrival of raw materials to production house }\end{array}$ & KPI 2 & 0,726 & 0.444 & Valid \\
\hline 3 & Level of raw material inventory & KPI 3 & 0,669 & 0.444 & Valid \\
\hline 4 & Internal workers relations in the purchasing division & - & 0,567 & 0.444 & Valid \\
\hline 5 & $\begin{array}{l}\text { Reliability of workers in planning raw materials so } \\
\text { that they can be used as efficiently as possible }\end{array}$ & - & 0,593 & 0.444 & Valid \\
\hline
\end{tabular}

Table 1 shows that the magnitude of the correlation coefficients from all questions consisting of 5 questions for the plan variable can be seen, it can be seen that the KPI for the variable plan is all valid, which means that all questions can explain the supply chain conditions in the variable plan. The validity test of source presented in table 2.

Table 2. Validity Test Source

\begin{tabular}{|c|c|c|c|c|c|}
\hline No. & Indicators & KPI & ${ }^{r}$ count & $\begin{array}{c}\mathrm{r}_{\text {table }} \\
(\mathrm{df}=\mathrm{n}-2, \alpha=5 \%)\end{array}$ & Validity \\
\hline 1 & $\begin{array}{l}\text { Responsibility of the raw material Suppliers to fulfill } \\
\text { the demand for raw materials }\end{array}$ & KPI 4 & 0,532 & 0.444 & Valid \\
\hline 2 & $\begin{array}{l}\text { Responsibility of the raw material Suppliers to fulfill } \\
\text { the demand for raw materials }\end{array}$ & KPI 5 & 0,855 & 0.444 & Valid \\
\hline 3 & Supplier on time to send the raw material & KPI 6 & 0,529 & 0.444 & Valid \\
\hline 4 & Standard quality of raw material & KPI 7 & 0,001 & 0.444 & invalid \\
\hline
\end{tabular}

Table 2. shows that KPIs for source variables have 3 valid and 1 invalid ones, namely questions related to the quality of raw materials. This is because the understanding of the quality of raw materials is not standard. If the raw material supplied is not good, it will affect the yield of palm sugar produced. The validity test of make category presented in table 3 .

Table 3. Test Validity of Make

\begin{tabular}{|c|c|c|c|c|c|}
\hline No. & Indicators & KPI & ${ }^{r}$ count & $\begin{array}{c}r_{\text {table }} \\
(d f=n-2, \alpha=5 \%)\end{array}$ & Validity \\
\hline 1 & $\begin{array}{l}\text { Reliability of worker to handling the raw material } \\
\text { used }\end{array}$ & KPI 8 & 0,599 & 0.444 & Valid \\
\hline 2 & The reliability of worker to process the raw material & KPI 9 & 0,719 & 0.444 & Valid \\
\hline 3 & $\begin{array}{l}\text { The production process runs well and meets the } \\
\text { quality standards }\end{array}$ & KPI 10 & 0,669 & 0.444 & Valid \\
\hline 4 & $\begin{array}{l}\text { Efficiency of material handling equipment in raw } \\
\text { material }\end{array}$ & KPI 11 & 0,544 & 0.444 & Valid \\
\hline 5 & $\begin{array}{l}\text { Efficiency of equipment used in handling finished } \\
\text { product }\end{array}$ & KPI 12 & 0,593 & 0.444 & Valid \\
\hline 6 & $\begin{array}{l}\text { Extra production costs at any time if there are } \\
\text { constraints in production }\end{array}$ & - & 0,374 & 0.444 & invalid \\
\hline
\end{tabular}




\begin{tabular}{|c|l|c|c|c|c|}
\hline 7 & $\begin{array}{l}\text { Changes in the cost of handling the production } \\
\text { process when it comes to storage }\end{array}$ & KPI 13 & 0,291 & 0.444 & invalid \\
\hline 8 & $\begin{array}{l}\text { The level of rejection of raw materials that are not } \\
\text { appropriate }\end{array}$ & KPI 14 & 0,454 & 0.444 & Valid \\
\hline 9 & $\begin{array}{l}\text { The reliability of workers in raw material } \\
\text { production }\end{array}$ & KPI 15 & 0,408 & 0.444 & invalid \\
\hline 10 & Workers' flexibility in fulfilling incoming orders & KPI 16 & 0,544 & 0.444 & Valid \\
\hline 11 & Product packaging process & KPI 17 & 0,144 & 0.444 & invalid \\
\hline
\end{tabular}

Table 3 shows that there are 11 questions for the make variable and there are 7 valid items while the other 4 are invalid, namely the question of adding production costs, changes in the cost of processing production, the performance of workers in producing raw materials and the product packaging process. The test of validity of deliver presented in table below

Table 4. Test of Validity of Deliver

\begin{tabular}{|c|c|c|c|c|c|}
\hline No. & Indicators & KPI & ${ }^{r}$ count & $\begin{array}{c}r_{\text {table }} \\
(d f=n-2, \alpha=5 \%)\end{array}$ & Validity \\
\hline 1 & Product reach consumers on time & KPI 18 & 0,532 & 0.444 & valid \\
\hline 2 & Product delivery quality & KPI 19 & 0,599 & 0.444 & valid \\
\hline 3 & $\begin{array}{l}\text { Changes in shipping costs due to certain } \\
\text { constraints }\end{array}$ & KPI 20 & 0,377 & 0.444 & invalid \\
\hline
\end{tabular}

Based on table 4 it is known that from the 3 questions for the variable deliver there are 2 validity questions and 1 invalid question item, namely changes in shipping costs due to certain constraints. This is because almost all producers do not need shipping costs where consumers, especially middleman, go directly to the production site. In addition, understanding of this question is relatively diverse. The validity test of return presented in table 5 .

Table 5. Validity test of Return

\begin{tabular}{|c|c|c|c|c|c|}
\hline No. & Indicators & KPI & $r_{\text {count }}$ & $\begin{array}{c}\mathrm{r}_{\text {table }} \\
(\mathrm{df}=\mathrm{n}-2, \alpha=5 \%)\end{array}$ & Validity \\
\hline 1 & $\begin{array}{l}\text { Complaints from consumers related to the } \\
\text { quality of goods and time }\end{array}$ & KPI 21 & 0.855 & 0.444 & valid \\
\hline 2 & $\begin{array}{l}\text { The manufacturer's response in replacing } \\
\text { damaged products }\end{array}$ & KPI 22 & 0,091 & 0.444 & invalid \\
\hline 3 & $\begin{array}{l}\text { Condition of the goods that do not fit the } \\
\text { current standard reimbursement }\end{array}$ & - & 0,719 & 0.444 & valid \\
\hline 4 & $\begin{array}{l}\text { The speed of time needed to replace a } \\
\text { defective product }\end{array}$ & KPI 23 & 0,402 & 0.444 & invalid \\
\hline
\end{tabular}

Table 5 shows that from 4 questions for return, there are 2 valid items and 2 invalid items. Invalid questions are found in the question regarding the manufacturer's response to the replacement of the damaged product and the speed of time needed to replace the defective product. This is because there are some farmers who do not want to answer related to the actual situation regarding defective products or not on demand.

\section{Reliability Test Results}

After testing the validity of 27 questions and producing 19 valid questions, the 8 questions will be tested to what extent the results of the questionnaire measurements have a level of reliability using reliability testing. The following are the values from the results of the reliability test. It is known that the reliability test results obtained by the reliability coefficient alpha of the study which is 0.918 have a cronbach alpha coefficient greater than the 
$\mathrm{r}$ table value (0.444). This means that the results of the questionnaire answers are consistent if measurements are taken in different times and places. Thus, the questionnaire used in this study has a good level of reliability so that it can be used to measure research data. The weight value for each level presented in table 6 and table 7 .

Table 6. Weight values for plan and source level

\begin{tabular}{|c|c|c|c|c|c|}
\hline $\begin{array}{l}\text { Process } \\
(\text { Level 1) }\end{array}$ & Weight & $\begin{array}{c}\text { Dimension } \\
(\text { level 2) }\end{array}$ & Weight & $\begin{array}{c}\text { Key Performance Indicator (KPI) } \\
\text { (Level 3) }\end{array}$ & Weight \\
\hline \multirow{5}{*}{ Plan } & \multirow{5}{*}{0.131} & \multirow{5}{*}{ Reliability } & \multirow{5}{*}{ - } & Predicting accuracy of raw material & 0.332 \\
\hline & & & & $\begin{array}{l}\text { The time span required between the order and } \\
\text { the time of arrival of raw materials to production } \\
\text { house }\end{array}$ & 0.09 \\
\hline & & & & Level of raw material inventory & 0.204 \\
\hline & & & & $\begin{array}{l}\text { Internal workers relations in the purchasing } \\
\text { division }\end{array}$ & 0.077 \\
\hline & & & & $\begin{array}{l}\text { Reliability of workers in planning raw materials } \\
\text { so that they can be used as efficiently as possible }\end{array}$ & 0.298 \\
\hline \multirow{3}{*}{ Source } & \multirow{3}{*}{0.369} & \multirow{2}{*}{ Reliability } & \multirow{2}{*}{0.666} & $\begin{array}{l}\text { Responsibility of the raw material Suppliers to } \\
\text { fulfill the demand for raw materials }\end{array}$ & 0.350 \\
\hline & & & & $\begin{array}{l}\text { Responsibility of the raw material Suppliers to } \\
\text { fulfill the demand for raw materials }\end{array}$ & 0.478 \\
\hline & & Responsiveness & 0.333 & Supplier on time to send the raw material & 0.172 \\
\hline
\end{tabular}

Table 7. Weight values for make, deliver and return level

\begin{tabular}{|c|c|c|c|c|c|}
\hline $\begin{array}{l}\text { Process } \\
(\text { Level 1) }\end{array}$ & Weight & $\begin{array}{c}\text { Dimension } \\
\text { (level 2) }\end{array}$ & Weight & $\begin{array}{c}\text { Key Performance Indicator (KPI) } \\
\text { (Level 3) }\end{array}$ & Weight \\
\hline \multirow{7}{*}{ Make } & \multirow{7}{*}{0.231} & \multirow{5}{*}{ Reliability } & \multirow{5}{*}{0.537} & $\begin{array}{l}\text { Reliability of worker to handling the raw } \\
\text { material used }\end{array}$ & 0.167 \\
\hline & & & & $\begin{array}{l}\text { The reliability of worker to process the raw } \\
\text { material }\end{array}$ & 0.103 \\
\hline & & & & $\begin{array}{l}\text { The production process runs well and meets the } \\
\text { quality standards }\end{array}$ & 0.239 \\
\hline & & & & $\begin{array}{l}\text { Efficiency of material handling equipment in } \\
\text { raw material }\end{array}$ & 0.179 \\
\hline & & & & $\begin{array}{l}\text { Efficiency of equipment used in handling } \\
\text { finished product }\end{array}$ & 0.183 \\
\hline & & Responsiveness & 0.268 & $\begin{array}{l}\text { The level of rejection of raw materials that are } \\
\text { not appropriate }\end{array}$ & 0.071 \\
\hline & & Flexibility & 0.194 & $\begin{array}{l}\text { Workers' flexibility in fulfilling incoming } \\
\text { orders }\end{array}$ & 0.055 \\
\hline \multirow{2}{*}{ Deliver } & \multirow{2}{*}{0.182} & \multirow{2}{*}{ Responsiveness } & \multirow{2}{*}{ - } & Product reach consumers on time & 0.251 \\
\hline & & & & Product delivery quality & 0.159 \\
\hline \multirow{2}{*}{ Return } & \multirow{2}{*}{0.085} & Responsiveness & 0.667 & $\begin{array}{l}\text { Complaints from consumers related to the } \\
\text { quality of product and time }\end{array}$ & 0.750 \\
\hline & & Flexibility & 0.333 & $\begin{array}{l}\text { Condition of the product that do not fit the } \\
\text { current standard reimbursement }\end{array}$ & 0.250 \\
\hline
\end{tabular}


The calculation of the final value of the supply chain flow performance is done by multiplying each normalization score with the weights in each KPI, dimensions and processes. Calculation of the final value of KPIs, the final value dimensions and the total value of supply chain performance in the palm sugar business are presented in tables 8,9 and table 10 .

Table 8. The final KPI values of plan process

\begin{tabular}{|c|c|c|c|c|c|c|c|c|}
\hline Process & Weight & Dimension & Weight & $\begin{array}{l}\text { Key Performance } \\
\text { Indicator }\end{array}$ & Score & Weight & $\begin{array}{l}\text { Performance } \\
\text { Score }\end{array}$ & $\begin{array}{l}\text { Total } \\
\text { Score }\end{array}$ \\
\hline \multirow{5}{*}{ Plan } & \multirow{5}{*}{0.131} & \multirow{5}{*}{ Reliability } & \multirow{5}{*}{ - } & $\begin{array}{l}\text { Predicting accuracy of } \\
\text { raw material }\end{array}$ & 76 & 0.332 & 25.232 & \multirow{5}{*}{74.297} \\
\hline & & & & $\begin{array}{l}\text { The time span required } \\
\text { between the order and } \\
\text { the time of arrival of raw } \\
\text { materials to production } \\
\text { house }\end{array}$ & 85 & 0.09 & 7.65 & \\
\hline & & & & $\begin{array}{l}\text { Level of raw material } \\
\text { inventory }\end{array}$ & 66 & 0.204 & 13.464 & \\
\hline & & & & $\begin{array}{l}\text { Internal workers } \\
\text { relations in the } \\
\text { purchasing division }\end{array}$ & 65 & 0.077 & 5.005 & \\
\hline & & & & $\begin{array}{l}\text { Reliability of workers in } \\
\text { planning raw materials } \\
\text { so that they can be used } \\
\text { as efficiently as possible }\end{array}$ & 77 & 0.298 & 22.946 & \\
\hline
\end{tabular}

Table 9. The final KPI values of source and make process

\begin{tabular}{|c|c|c|c|c|c|c|c|c|}
\hline Process & Weight & Dimension & Weight & $\begin{array}{l}\text { Key Performance } \\
\text { Indicator }\end{array}$ & Score & $\begin{array}{c}\text { Weig } \\
\mathrm{ht}\end{array}$ & $\begin{array}{c}\text { Performance } \\
\text { Score } \\
\end{array}$ & $\begin{array}{l}\text { Total } \\
\text { Score }\end{array}$ \\
\hline \multirow{3}{*}{ Source } & \multirow{3}{*}{0.369} & \multirow{2}{*}{ Reliability } & \multirow{2}{*}{0.666} & $\begin{array}{l}\text { Responsibility of the raw } \\
\text { material Suppliers to } \\
\text { fulfill the demand for } \\
\text { raw materials }\end{array}$ & 76 & 0.350 & 26.6 & \multirow{3}{*}{79.48} \\
\hline & & & & $\begin{array}{l}\text { Responsibility of the raw } \\
\text { material Suppliers to } \\
\text { fulfill the demand for } \\
\text { raw materials }\end{array}$ & 84 & 0.478 & 40.152 & \\
\hline & & $\begin{array}{l}\text { Responsive } \\
\text { ness }\end{array}$ & 0.333 & $\begin{array}{l}\text { Supplier on time to send } \\
\text { the raw material }\end{array}$ & 74 & 0.172 & 12.728 & \\
\hline \multirow{6}{*}{ Make } & \multirow{6}{*}{0.231} & \multirow{5}{*}{ Reliability } & \multirow{5}{*}{0.537} & $\begin{array}{l}\text { Reliability of worker to } \\
\text { handling the raw } \\
\text { material used }\end{array}$ & 76 & 0.167 & 12.692 & \multirow{6}{*}{71.361} \\
\hline & & & & $\begin{array}{l}\text { The reliability of worker } \\
\text { to process the raw } \\
\text { material }\end{array}$ & 86 & 0.103 & 8.858 & \\
\hline & & & & $\begin{array}{l}\text { The production process } \\
\text { runs well and meets the } \\
\text { quality standards }\end{array}$ & 66 & 0.239 & 15.774 & \\
\hline & & & & $\begin{array}{l}\text { Efficiency of material } \\
\text { handling equipment in } \\
\text { raw material }\end{array}$ & 64 & 0.179 & 11.456 & \\
\hline & & & & $\begin{array}{l}\text { Efficiency of equipment } \\
\text { used in handling finished } \\
\text { product }\end{array}$ & 77 & 0.183 & 14.091 & \\
\hline & & Responsive & 0.268 & The level of rejection of & 70 & 0.071 & 4.97 & \\
\hline
\end{tabular}




\begin{tabular}{|l|l|l|l|l|l|c|} 
& ness & $\begin{array}{l}\text { raw materials that are not } \\
\text { appropriate }\end{array}$ & & \\
\cline { 2 - 5 } & Flexibility & 0.194 & $\begin{array}{l}\text { Workers' flexibility in } \\
\text { fulfilling incoming } \\
\text { orders }\end{array}$ & 64 & 0.055 & 3.52 \\
\hline
\end{tabular}

Table 10. The final KPI values of deliver and return process

\begin{tabular}{|c|c|c|c|c|c|c|c|c|}
\hline Process & Weight & Dimension & Weight & $\begin{array}{l}\text { Key Performance } \\
\text { Indicator }\end{array}$ & Score & Weight & $\begin{array}{c}\text { Performance } \\
\text { Score }\end{array}$ & $\begin{array}{l}\text { Total } \\
\text { Score }\end{array}$ \\
\hline \multirow{2}{*}{ Deliver } & \multirow{2}{*}{0.182} & \multirow{2}{*}{$\begin{array}{c}\text { Responsivene } \\
\text { ss }\end{array}$} & \multirow{2}{*}{ - } & $\begin{array}{l}\text { Product reach } \\
\text { consumers on time }\end{array}$ & 76 & 0.251 & 19.076 & \multirow{2}{*}{31.16} \\
\hline & & & & $\begin{array}{l}\text { Product delivery } \\
\text { quality }\end{array}$ & 76 & 0.159 & 12.084 & \\
\hline \multirow{2}{*}{ Return } & \multirow{2}{*}{0.085} & $\begin{array}{l}\text { Responsivene } \\
\text { ss }\end{array}$ & 0.667 & $\begin{array}{l}\text { Complaints from } \\
\text { consumers related to } \\
\text { the quality of product } \\
\text { and time }\end{array}$ & 84 & 0.750 & 63 & \multirow{2}{*}{84.5} \\
\hline & & Flexibility & 0.333 & $\begin{array}{l}\text { Condition of the } \\
\text { product that do not fit } \\
\text { the current standard } \\
\text { reimbursement }\end{array}$ & 86 & 0.250 & 21.5 & \\
\hline
\end{tabular}

Table 11. Calculation of Total Performance Value

\begin{tabular}{|c|c|c|c|}
\hline Process & Score & Weight & Total score \\
\hline Plan & 74.297 & 0.131 & 9.733 \\
\hline Source & 48.695 & 0.369 & 17.968 \\
\hline Make & 35.777 & 0.231 & 8.264 \\
\hline Deliver & 31.16 & 0.182 & 5.671 \\
\hline Return & 49.181 & 0.085 & 4.180 \\
\hline & Total & 46 \\
\hline
\end{tabular}

The performance of the business supply chain of palm sugar is in the Average category with a score of 46 . The weight of the core variable is based on the order of priority are source of 17.97, plan of 9,733, make of 8,264, deliver 5,671 and return of the lowest weight of 4,180. The priority of supply chain performance improvement in palm sugar business is by increasing the performance of return process.

\section{CONCLuSions}

In this paper, he results of implementing SCOR model with AHP to analyse the supply chain of palm sugar business was presented. The results show that the supply chain flow performance in the palm sugar business amounted to 46 which means that the supply chain performance in this business is in the marginal or moderate performance indicator. The final value shows that the highest performance is in the source process and the lowest performance in the return process. This means that the return process requires priority improvements in this palm sugar business.

\section{ACKNOWLEDGMENT}

The authors thank the financial support of the Directorate General for the Research and Community Service Institution of Hasanuddin University, Indonesia. 


\section{REFERENCES}

[1] A.S. Hosseini, A. Soltani and M. Mehdizadeh. "Competitive Advantage and Its Impact on New Product Development Strategy (Case Study: Toos Nirro Technical Firm)”. Journal of Open Innovation: Technology, Market, and Complexity, vol. 4 no 17, pp. 1-12, 2018.

[2] T.W. Kaunyangi, 2014. "The Impact of Competition on Performance of Firms in the Mobile Telecommunication Sector in Kenya". International Journal of Scientific and Research Publication, vol. 4 no 1, pp. 1 -7, 2014.

[3] Golban, A, "The analysis of Competitiveness and Competitive advantage of the Horticultural Production from the Republic of Moldova: Challenges and opportunities” Agricultural Economic and Rural Development, vol. XII no. 1, pp .27-43, 2015.

[4] M.J. Eskandari, M. Miri, S. Gholami S, and H.R.S. Nia H.R.S, "Factors Affecting the Competitiveness of the Food Industry by Using Porte's Five Forces Model. Case study in Hamadan Province, Iran”. Journal of Asian Scientific Research, Vol 5 (4), 185 - $19,2015$.

[5] Y. Yiannakopoulos, A. Magoutas, and Chountalas. "Strategic competition Analysis and Group Mapping: The Case of the Greek Insurance Industry”. Journal of Economic and Business, vol. 20 no 1, pp. 41-65, 2017.

[6] J.R. Ocampo, J.C. Hernandez-Matias, and A. Vizan A, "Method for Estimating Manufacturing Competitiveness: The Case of the Apparel Maquiladora Industry in Central Amerika”. DYNA, vol. 84 no 200, pp 97-106, 2016

[7] G.E. Delipinar, B. kocaoglu B, "Using SCOR model to gain competitive advantage: A literature review". Procedia-Social and Behavioral Sciences, vol 229, pp. 398 - 406, 2016.

[8] B. Kocaoğlu, B. Gülsün, and M. Tanyaş M, "A SCOR based approach for measuring a benchmarkable supply chain performance". Journal of Intelligent Manufacturing, vol. 24, pp. 113-132, 2013.

[9] A.M. Janvier-James, “A New Introduction to Supply Chains and Supply Chain Management: Defenitions and Theories Perspective". International Business Research, vol. 5 no 1, pp 194-2017, 2012.

[10] P. Kumar, D. Kumar, and Seema. "Measurement of Effectiveness of Flexibility in Sustainable Supply Chain". International Journal of Science and Management Studies, vol 1 no 3, pp. 7-11, 2018.

[11] A.M. Janvier-James, "A New Introduction to Supply Chains and Supply Chain Management: Definitions and Theories Perspective". International Business Research, Vol. 5 no. 1, pp. 194-2017, 2012.

[12] E.N. Ntabe, L. leBel, A.D. Munson, L.A. Santa-Eulalia, 2014. A Systematic Literature Review of the Supply Chain Operations Reference (SCOR) Model Application with Spesial Attention to Environmental Issue. Interuniversity Research Centre on Enterprise Networks, Logistics and Transportation. CIRRELT, Canada, 2014

[13] M. Dopalvar and M. Siefbarghy, “Application of SCOR Model in an Oil-Producing Company”. Journal of Industrial Engineering, vol 4, pp. 59-69, 2019.

[14] A. Girjatovičs, L.M. Rizoto-Vidala-Pesoa, O. Kuznecova. "Implementation of SCOR Based Business Process Framework for Logistics and Supply Chain in Retail Company". Information Technology and Management Science, vol.21, pp. 69-74, 2018.

[15] Pujawan I.N. 2005. Supply Chain Management. Guna Widya, Surabaya 